\title{
Institutional Ownership, Board of Directors and Yield Spreads in Long- and Medium-term Corporate Bonds and Sukuk
}

\author{
Noriza, Mohd Saad (Corresponding author) \\ Department of Finance and Economics, Universiti Tenaga Nasional, 26700 Muadzam Shah, \\ Pahang, Malaysia \\ Tel: +6013-3329141 E-mail: Noriza@uniten.edu.my \\ Mohd Nizal Haniff \\ Faculty of Accountancy, Universiti Teknologi MARA, 40450 Shah Alam, Selangor, Malaysia \\ Tel: +603-55442000 E-mail: mohdnizal@salam.uitm.edu.my \\ Norli Ali \\ Faculty of Accountancy, Universiti Teknologi MARA, 40450 Shah Alam, Selangor, Malaysia \\ Tel: +603-55442000 E-mail: norli@salam.uitm.edu.my
}

\begin{abstract}
Previous studies documented that type of investor significantly affects the performance of bonds and sukuk. These studies showed that the yield to maturity (YTM) of bonds and sukuk are significantly associated with institutional investors. This association is because institutional investors actively monitor the performance of bonds and sukuk. Apart from the type of investor, the roles played by the board of directors (BOD) in decision making significantly influence the performance of bonds and sukuk, especially the YTM. This study aims to investigate the relationship between institutional ownerships and the BOD and yield spreads of long- and medium-term corporate bonds and sukuk. Data are obtained from firm issuers' annual reports, Bond Info Hub of Malaysia Central Bank, Department of Malaysia Statistics and Bloomberg from 2000 to 2014. The study employed unbalanced panel data approach for multivariate robust regression, OLS, fixed-effect, and random-effect models. Results revealed that the presence of top-six institutional investors and characteristics of the BOD exert a significant negative effect on the yield spreads. The findings are also consistent with the agency cost of debt theory, which suggests that long-term bonds carry a lower cost of defaults than medium-term bonds.
\end{abstract}

Keywords: Institutional Ownership; Board of Directors; Yield Spreads; Corporate Bonds; Sukuk

\section{Introduction}

Bonds have been increasingly but slowly supplementing bank lending as a source of finance for the private sector in emerging market economies. In the United States, bond financing has long ago overtaken borrowing from domestic banks (Hawkins, 2002). Hawkins (2002) mentioned that this competition between public issued bonds and banks significantly affect banking systems. Therefore, the development of a bond market was viewed as a priority because it served as an alternative source for raising capital (Sharma, 2001; Zakaria, Hussin, Noordin, \& Mohamed Sawal, 2010). In recent decades, the development of Islamic capital market (ICM), especially sukuk has given another alternative of source of financing. Hesse, Jobst, and Sole (2008) stated that the development of ICM assets and structured finance in several Islamic jurisdictions countries, such as Bahrain, Malaysia, and Dubai, has encouraged participation from shariahcompliant debt issuance in a bid to promote themselves as centers for Islamic finance. The leading financial centers (e.g., Hong Kong, London, New York, and Singapore) are making 
significant progress in establishing legal and prudential foundations to accommodate Islamic finance alongside the conventional financial system, including sukuk market.

In Malaysia, sukuk share similar features to conventional bonds. Sukuk has maturity period, coupon rate, and trades on normal yield price relationship. The difference between these two instruments is the underlying asset for conventional bonds is money (debt) and that of sukuk is an asset (Afshar, 2013). Sukuk is structured such that the issuance is not an exchange between paper and money and does not impose interest (yields), unlike conventional bonds. The issuance of sukuk is based on an exchange of approved assets for financial consideration that allows investors to earn profits from the transactions. Approval of the assets and the contract of exchange are based on shariah principles. On the contrary, conventional bonds are standard bonds bearing a coupon, that requires payment of interest either yearly, twice a year, or quarterly. Conventional bonds also have a maturity date at which investors will redeem their bonds at face value or par value. The price of conventional bonds changes primarily with the interest rate, which can include trading activities that are deemed prohibited and are regarded unsuitable for Muslim investors. Unlike bonds, the yields on sukuk are based on profit from transaction and not from interest or any prohibited activities. Past studies showed that the yield on sukuk and bonds are associated with several factors, such as ownership structures, corporate governance, macroeconomic factors, and others. This study aims to examine whether the institutional ownership and characteristics of the board of directors (BOD) can influence the performance of sukuk and bonds. The study also intends to investigate whether tenure plays a crucial role in determining yield to maturity (YTM) and risk of default.
The remainder of this paper is organized as follows. The next section briefly discusses corporate governance, institutional investor, BOD, and agency cost of debt theory. The section after that presents the the research methods and findings.

\section{Corporate Governance, Institutional \\ Investor, BOD, and Agency Theory}

Several researchers have studied the impact of corporate governance mechanisms on the reduction of default risks of conventional bonds by mitigating agency costs and monitoring managerial performance between the firm and the lenders (e.g., Berle \& Means, 1932; Bhojraj \& Sengupta, 2003). Given the role of institutional investors in monitoring the performance of companies (Mallin, 2008; Elyasiani \& Jia, 2010), these investors are considered as advanced investors and are better in utilizing current information to predict future earnings than other types of shareholders (Jiambalvo, Rajgopal, \& Venkatachalam, 2002) as well as in bidding to increase liquidity and enhance transparency (Jobst, 2006).

The relationship between agent and principal in the issue of separation and control leads to agency conflict (Fama \& Jensen, 1983; Jensen \& Meckling, 1976). Jensen and Meckling (1976) emphasized the diversion of the managers' interest from that of the owners, which leads to the agency conflict of interest often referred to as agency problem (Fama \& Jensen, 1983). Agency problem arises because any financing contract is not costless, written, and enforced (Fama \& Jensen, 1983). Agency costs include the cost of structuring, monitoring, and bonding a set of contracts among agents with conflicting interests (Jensen \& Meckling, 1976). Control of agency problems in the decision process is important when the decision made by the BOD and managers who initiate and implement important decisions are not the major residual claimants and therefore do not bear a major 
share of the wealth effects of their decisions (Fama \& Jensen, 1983).

Without effective controlling and monitoring mechanism, such a management decision of the BOD is likely to take actions that deviate from the interests of residual claimants. An effective system for decision control implies that the control focus on the ratification and monitoring of decisions and should be separate from the management during initiation and implementation of decisions to a certain extent. Individual decision agents can be involved in the management of specific decisions and the control of others, but separation means that an individual agent does not exercise exclusive management and control rights over the same decisions (Jensen \& Meckling, 1976; Fama \& Jensen, 1983).

As a governance mechanism, institutional investors and the BOD are beneficial to bondholders (Jensen \& Meckling, 1976; Fama \& Jensen, 1983; Bhojraj \& Sengupta, 2003; López-iturriagaa \& García-meca, 2015). The presence of institutional investors who have purchased corporate bonds and sukuk rather than that of individual investors helps reduce the cost of debt and increases the benefit of monitoring with the duration of the investment. In addition, their share ownerships in the issuer firm are strong incentives to monitor the firm's management, thereby reducing the cost of debt and consequently mitigating default risk (Barry, Lepetit, \& Tarazi, 2011) and enhancing the firm performance in the long run toward debt policy planning decisions (Qiu, 2006). Instead of a negative relationship with yield spreads, the presence of this institutional ownership exerts a significant positive effect on yield spreads in multinational firms (Boubakri \& Ghouma, 2010).

Past studies documented that an issuer firm with effective BOD characteristics, as highlighted in the Malaysia Code of Corporate Governance (MCCG) code of best practices, can reduce default risk. BOD characteristics, including
CEO duality, BOD composition, and board size, are important because they influence corporate bond markets (Tanaka, 2014). A CEO who has considerable decision-making power is associated with high yield spreads. Powerful CEOs tend to maintain an opaque information environment and become a critical determinant to the cost of bond financing (Liu \& Jiraporn, 2010; Shailer \& Wang, 2015). CEO duality positively affects firm performance, and separating the roles of CEO and chairman is associated with low yield spreads (John \& Senbet, 1998; Liu \& Jiraporn, 2010).

In addition, excellent board experience may lead to good quality advice to management and effective terms for debt. The quality of the board includes BOD composition, and this characteristic exerts a material impact on low corporate debt yield spreads. A large number of independent directors can reduce a firm's cost of capital because many directors can provide multitasking skills and qualifications that generate a broad perspective in decision making (Bhojraj \& Sengupta, 2003; Ertugrul \& Hegde, 2008; Fields, Fraser, \& Subrahmanyam, 2012) that can enhance efficient monitoring (John \& Senbet, 1998) and advising functions as well as create much value (Andres \& Vallelado, 2008). Consequently, board size has a significant negative relationship with debt financing (Huang \& Wang, 2015; John \& Senbet, 1998) and bond yield spreads (Anderson, Mansi, \& Reeb, 2004; Ertugrul \& Hegde, 2008; Fields, Fraser, \& Subrahmanyam, 2012). However, despite the importance of BOD characteristics, no prior research has explored their influence on sukuk yield spreads in long and medium terms.

\section{Methodology}

The data of this study are gathered from various sources, including Bank Negara Malaysia, RAM, SC, Bloomberg and Department of Statistics, Malaysia. Specifically, data are retrieved from Bond Info Hub's website from BNM for issuance characteristics for conventional bonds and sukuk, including yield, number of tranches, 
issuer name, price of debt, issue date, maturity date, issue amount in millions (MYR), and debt instrument categories. Table 1 summarizes the variables used and their measurement as along with the data sources.
All the data are sorted, screened, and matched. Firms with missing data are omitted, leaving the total usable observation data for the long-term debt instruments of 140 issuer firms with 256 tranches from 2000 to 2014. In medium-term debt instruments, the total usable observation data are 160 issuer firms with 395 tranches from 2003 to 2014.

Table 1: Data Description, Proxy/

Measurement, Predicted Sign, and Data Sources

\begin{tabular}{|c|c|c|c|c|c|}
\hline No. & Variables & Description & Proxy/M easurement & Predicted & Data \\
\hline & \multicolumn{5}{|c|}{ Dependent: } \\
\hline 1 & $\begin{array}{l}\text { Yield } \\
\text { Spreads }\end{array}$ & YTM & $\begin{array}{l}\text { Max of YTM minus min of YTM of bonds \& sukuk } \\
\text { issues minus with T-bills on matched issuance date } \\
\text { for long- and medium- term issued. }\end{array}$ & & $\begin{array}{l}\text { BNM } \\
\text { RAM \& } \\
\text { SC }\end{array}$ \\
\hline & \multicolumn{5}{|c|}{ Independent: } \\
\hline & \multicolumn{5}{|c|}{ Institutional Ownerships: } \\
\hline 2 & Top-Six IO & Gov & $\begin{array}{l}\text { The total percentage of share ownership by six } \\
\text { institutional owners of public listed firms. }\end{array}$ & - & \multirow{2}{*}{$\begin{array}{l}\text { Annual } \\
\text { Report }\end{array}$} \\
\hline 3 & Others IO & All IO & $\begin{array}{l}\text { The total percentage of share ownership by all inst. } \\
\text { owners of public listed firms except top-6 IO. }\end{array}$ & - & \\
\hline & \multicolumn{5}{|c|}{ BOD Characteristics: } \\
\hline 4 & BODR2 & $\begin{array}{l}\text { CEO \& } \\
\text { chairman }\end{array}$ & $\begin{array}{l}\text { Dichotomous variable. } 1 \text { if combined position of } \\
\mathrm{CEO} \text { and chairman and } 0 \text { if separated position. }\end{array}$ & - & \multirow{4}{*}{$\begin{array}{l}\text { Annual } \\
\text { Report }\end{array}$} \\
\hline 5 & BODC & $\begin{array}{l}\text { \#of } \\
\text { directors }\end{array}$ & $\begin{array}{l}\text { Dichotomous variable. } 1 \text { if independent director less } \\
\text { than } 1 / 3 \text { and } 0 \text { if independent director }=@>1 / 3 \text {. }\end{array}$ & - & \\
\hline 6 & BODS & \#of director & Total number of directors in the firm. & - & \\
\hline 7 & BODM & $\begin{array}{l}\text { Muslim } \\
\text { directors }\end{array}$ & $\begin{array}{l}\text { Total percentage for number of Muslim directors } \\
\text { over total number of directors. }\end{array}$ & $?$ & \\
\hline & \multicolumn{5}{|l|}{ Control: } \\
\hline 8 & Volatility & Price of debt & $\begin{array}{l}\text { Maximum minus minimum price for each tranches of } \\
\text { conventional bonds and sukuk. }\end{array}$ & + & \multirow{3}{*}{$\begin{array}{l}\text { BNM, } \\
\text { RAM \& } \\
\quad \text { SC }\end{array}$} \\
\hline 9 & $\operatorname{lnSize}$ & Issue & $\log$ of amount of issue in M YR (millions). & - & \\
\hline 10 & Tenure & Year & Maturity year period minus with issue year period. & + & \\
\hline 11 & Profit & $\mathrm{ROA}$ & Net income divided by total assets. & + & Bloom- \\
\hline 12 & Leverage & $\mathrm{TA} / \mathrm{TE}$ & Total assets divided by total equity. & - & berg \\
\hline 13 & Firm Value & Tobin's Q & $\begin{array}{l}\text { Total of market value of equity with book value } \\
\text { preferred stock and book value of LTD/TA. }\end{array}$ & + & \\
\hline 14 & Firm Size & $\ln \mathrm{TA}$ & Log of total short-term assets and long-term assets. & + & \\
\hline 15 & Sustain & SGR & $\begin{array}{l}\text { Return on common shares equity times with one } \\
\text { minus dividend payout ratio over } 100 \text {. }\end{array}$ & - & \\
\hline 16 & $\operatorname{lnGDP}$ & $\begin{array}{l}\text { Current } \\
\text { Prices }\end{array}$ & $\begin{array}{l}\text { Log of current price of Malay sian gross domestic } \\
\text { product for each year issued. }\end{array}$ & - & $\begin{array}{l}\text { Msian } \\
\text { Statistics }\end{array}$ \\
\hline
\end{tabular}




\section{Multivariate Panel Robust Regressions (MPRR)}

The study used MPRR to test the relationships between the dependent and independent variables.

The OLS model has treated standard error of estimations represented by $\varepsilon$ as identically and independently distributed disturbances that are uncorrelated with the correlations of standard error for independent variables, $\mathcal{X}$ , or $\operatorname{Cor}\left(\varepsilon_{i}, \mathrm{x}_{i}\right)=0$. In this case, the data can be pooled, and OLS can be used to estimate the model by denoting the estimator of the slope

$\beta_{O L S}$. The intercept and slope coefficients are constant across $N$ and $T$ represented by tranche issuances of each issuer, postulating that both the intercept and slope are the same across observations. However, these assumptions may be restrictive and lead to heterogeneity bias that must be handled for the robustness check analysis. Otherwise, the model does not require any additional technique for such estimations. The regression model equation for pooled OLS can be represented as follows: restricting the slope to be homogenous for yield spreads. Their spread is probably in random effect as liquidity movement requires regressions to accommodate such a heterogeneity. The random-effect model decomposes into two

composite error terms as $\varepsilon_{i t}=\lambda_{i}+u_{i}$.

\section{Results and Discussion}

\section{Analysis of Normality Tests and Descriptive Results}

The empirical data used in this study have been tested for normal or symmetrical distribution. De Vaus (2002), Tabachnick and Fidell (2007), and Howell (2007) stated that for secondary data to be non-symmetrical is normal. Following Tabachnick and Fidell (2007) and Howell (2007), options for handling non-normal data are several. The data can be transformed to enable further statistical analyses, including natural $\log$ transformation, to solve normality data problems especially for secondary data. Data transformation is based on the types and degree of violation as well as the randomness of

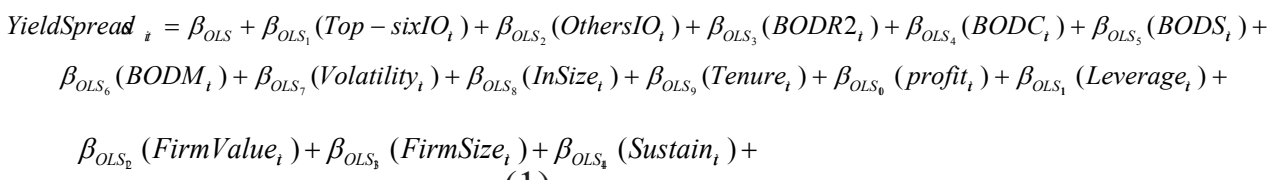

$\lambda_{i} x_{i t}$ The fixed-effect model is used when the constant value for each tranche of issuances, is correlated with the independent variables of the issuers for the year, and within variation in the data only but is the most flexible in that it allows for the endogeneity of regressors. Where

$\beta_{\varepsilon}=$ the coefficient estimates in fixed effect of the explanatory variables,

$\left(\beta_{\hat{k}}+\lambda_{i}\right)=$ the intercept for fixed effect, and $u_{i t}=$ the error term for fixed effect.

The random-effect model assumes that the tranche of issuances has intercepts while the missing data. In this study, three variables, namely, size of issuances, total assets, and current prices of GDP have been transformed to natural log transformation due to large range of data. Other variables, such as CEO duality and BOD composition, are dichotomous variables (two types of categories valued as either 0 or 1 ), and, thus, natural log transformation is inappropriate for these two variables.

Table 2 shows that most of the variables are normally distributed in long and medium terms. However, the Kolmogorov-Smirnov test is biased by sample size, and the test may be statistically significant from a normal distribution in any large sample. Therefore, this 
study reconfirms the results of normality test by performing another two tests (i.e., skewness and kurtosis). Based on the skewness and kurtosis test results, the shape of a probability distribution for both skewness and kurtosis is positively and negatively skewed. Ten variables show p-value $>0.01$, indicating that the data are non-normal according to the Z-score, which is proxied by the standard score value. The variables involved are yield spreads, top-six IO, other IO, BODR2, BODC, volatility, tenure, leverage, firm value, and sustain. The kurtosis test results show that the probability of data distributions are fat or short-tailed (platykurtic) and slim or longtailed (leptokurtic) as the standard score values which represent the Z-scores are not within the range of -3.29 and +3.29 (normal distribution range). The affected variables for LTCBS are yield spreads, top-six IO, BODR2, BODC, volatility, tenure, profit, firm value, firm size, sustain, and lnGDP. Another five variables have a normal distribution or mesokurtic, i.e., other
IO, BODS, BODM, lnSize, and leverage. The $\mathrm{Z}$-score values fall within the range of -3.29 and +3.29 , suggesting that the distribution of the corporate bonds and sukuk tranche spreads are positively and negatively skewed and that they are flatter than expected for a normal distribution. In addition, although the data are transformed to logarithm, the normality test by kurtosis continues to capture non-normality for variables such as firm size (log of total assets) and curren1t prices of GDP (log of GDP). Regardless whether the 10 variables in long-term issuances are non-normal in terms of probability distribution for data according to skewness test results for $p$-value $>0.01$, the number of variables increases to 12 in mediumterm issuances. The MTCBS for kurtosis test shows that the probability distribution of tranche spreads for the 11 variables as reported earlier also show that the standard score values are not within the range of -3.29 and +3.29 .

Table 2: Normality and Descriptive Results

\begin{tabular}{|c|c|c|c|c|c|c|c|c|c|c|c|c|}
\hline \multirow{3}{*}{ Variables } & \multicolumn{2}{|c|}{ Kolmogorov-Smirnov } & \multicolumn{2}{|c|}{ Skewness } & \multicolumn{2}{|c|}{ Kurtosis } & \multicolumn{6}{|c|}{ Descriptive Statistics } \\
\hline & LTCBS & MTCBS & LTCBS & MTCBS & LTCBS & MTCBS & \multicolumn{3}{|c|}{ LTCBS } & \multicolumn{3}{|c|}{ MT CBS } \\
\hline & \multicolumn{6}{|c|}{ Statistic } & Mean & Max & Min & Mean & Max & Min \\
\hline \multicolumn{13}{|l|}{ Dependent: } \\
\hline Yield Spreads & 2.095 & 1.815 & 4.185 & 1.524 & 32.8 & 2.982 & 2.16 & 18.06 & -0.52 & 1.59 & 5.16 & -0.2 \\
\hline \multicolumn{13}{|c|}{ Institutional Ownership: } \\
\hline Top-six IO & 1.394 & 1.305 & 1.639 & 1.467 & 2.396 & 1.618 & 15.993 & 83.84 & 0 & 16.061 & 80.79 & 0 \\
\hline Others IO & 1.638 & 1.701 & -0.849 & -0.42 & 0.405 & -0.944 & 56.586 & 98.77 & 0 & 48.454 & 92.037 & 0 \\
\hline \multicolumn{13}{|c|}{ BOD Characteristics: } \\
\hline BODR2 & 1.221 & 1.165 & 0.874 & 1.908 & -1.246 & 1.648 & 0.301 & 1.000 & 0.000 & 0.156 & 1.000 & 0.000 \\
\hline BODC & 0.173 & 1.012 & 6.337 & 3.569 & 38.461 & 10.793 & 0.023 & 1.000 & 0.000 & 0.064 & 1.000 & 0.000 \\
\hline BODS & 1.087 & 1.92 & 0.405 & 0.227 & -0.673 & -0.175 & 9.102 & 16.000 & 5.000 & 9.146 & 17.000 & 4.000 \\
\hline BODM & 1.221 & 3.085 & -0.324 & 0.315 & -0.705 & -1.189 & 55.408 & 100.000 & 0.000 & 47.248 & 100.000 & 0.000 \\
\hline \multicolumn{13}{|c|}{ Issue Characteristics: } \\
\hline Volatility & 2.299 & 1.867 & 2.779 & 2.468 & 10.156 & 11.261 & 1.342 & 11.06 & 0 & 0.649 & 6.2 & -0.26 \\
\hline $\ln \mathrm{Size}$ & 2.425 & 1.937 & 0.309 & -0.042 & -0.435 & -0.449 & 4.548 & 9.155 & 0.693 & 4.68 & 8.518 & 0.642 \\
\hline Tenure & 2.213 & 1.181 & 4.764 & 0.798 & 37.484 & -0.116 & 11.148 & 100 & 1 & 5.978 & 18 & 1 \\
\hline \multicolumn{13}{|c|}{ Issuer Characteristics: } \\
\hline Profit & 1.677 & 2.878 & -0.558 & 1.027 & 4.396 & 3.471 & 2.758 & 21.537 & -13.26 & 4.831 & 26.917 & -11.379 \\
\hline Leverage & 2.748 & 3.217 & 1.232 & 2.354 & 0.358 & 5.19 & 5.417 & 20.509 & 1.103 & 4.297 & 22.787 & 1.094 \\
\hline Firm Value & 2.134 & 2.894 & 1.237 & 3.34 & 2.387 & 14.526 & 1.074 & 2.19 & 0.513 & 1.233 & 4.717 & 0.622 \\
\hline Firm Size & 1.472 & 3.369 & 0.016 & -0.338 & -1.372 & -0.356 & 8.876 & 13.37 & 4.189 & 8.274 & 12.934 & 3.16 \\
\hline Sustain & 1.465 & 2.67 & 4.788 & -7.072 & 33.715 & 54.032 & 7.516 & 66.456 & -12.24 & 4.294 & 86.452 & -317.74 \\
\hline \multicolumn{13}{|c|}{ Systematic Risks: } \\
\hline $\operatorname{lnGDP}$ & 2.693 & 1.944 & -0.025 & -0.905 & -1.523 & 0.137 & 13.329 & 13.877 & 12.773 & 13.615 & 13.877 & 12.945 \\
\hline
\end{tabular}


The descriptive statistics results show slight difference in mean (almost 16\%), standard deviation (around 18\%), and maximum value (approximately 80\%) in both issuer firms, LTCBS and MTCBS for the top-six institutional ownerships. This outcome suggests that the presence of top-six institutional ownerships in long-term and medium-term issuances are similar as represented by their equity shareholdings owned in the firm. With respect to other institutional ownerships, LTCBS issuer firms indicate higher mean value than MTCBS as well as higher maximum value. This finding suggests that most of them have higher presence in firms that issue more LTCBS than MTCBS, and they focus on obtaining long-term investment for financing their business transactions. The issuer firms for both debt instruments, either LTCBS or MTCBS, have more directors that hold separate positions between $\mathrm{CEO}$ and chairman because their mean value is less than 0.301 and 0.156 , respectively. This separate position also enhances top management performance in making decisions among issuer firms because the standard deviation value are low at 0.459 and 0.363 for firms that issue LTCBS and MTCBS, respectively. This finding indicates the low risk involved in performing leadership role because they have a clear job description as highlighted and disclosed in the BOD statement included in the annual report of companies.

\section{Analysis of Pairwise Correlations and Variance Inflation Factor (VIF) Coefficients}

As reported in the correlation matrix in Table 3 , mixed positive and negative correlation results are noted in both panels A and B between yield spreads and independent variables via conventional bonds or sukuk issuances for both observations either long or medium term. These findings are not only for reports on the correlation results between dependent and independent variables but also among variables as revealed by the coefficient of estimations. The results show that none of the correlation coefficients regressors among variables in both panels A and B are larger than the value of 0.80 . Coefficient regressors with a value larger than 0.80 signifies a multicollinearity problem, which allows for omitting the variables (Damodar, 2004). The highest coefficient correlations regressors from both panels show less than the threshold $(<0.80)$, so the multicollinearity is not a serious problem in multiple regression analysis (Nguyen et al., 2015).

Table 3: Results of Pairwise Correlations and VIF for LTCBS and MTCBS

\begin{tabular}{|c|c|c|c|c|c|c|c|c|c|c|c|c|c|c|c|c|c|c|c|}
\hline No. & Variables & - & VIF & 1 & 2 & 3 & 4 & 5 & 6 & 7 & 8 & 9 & 10 & 11 & 12 & 13 & 14 & 15 & 16 \\
\hline 1 & Y spread & & & 1 & & & & & & & & & & & & & & & \\
\hline \multirow{2}{*}{2} & Top-6 IO & a & 3.04 & -.077 & 1 & & & & & & & & & & & & & & \\
\hline & & b & 3.17 & $-.175^{* * * *}$ & & & & & & & & & & & & & & & \\
\hline \multirow{2}{*}{3} & Other IO & a & 2.14 & .081 & $-.684^{* * * * * * *}$ & 1 & & & & & & & & & & & & & \\
\hline & Sotice & b & 2.43 & $-0.082 *$ & $-.369^{* * * * *}$ & & & & & & & & & & & & & & \\
\hline \multirow{2}{*}{4} & BODR2 & a & 2.06 & $.172^{* * * *}$ & $-.374^{* * * * * *}$ & $.305^{* * * * * * *}$ & 1 & & & & & & & & & & & & \\
\hline & BUDR2 & b & 1.36 & -.051 & $-.166^{* * * *}$ & $-.150^{* * * *}$ & 1 & & & & & & & & & & & & \\
\hline \multirow{2}{*}{5} & BODC & a & 1.11 & .003 & $-0.105^{*}$ & $.151^{* * *}$ & .011 & 1 & & & & & & & & & & & \\
\hline & DUD & b & 1.15 & .041 & -.038 & $.145^{* * * *}$ & $-0.085^{*}$ & 1 & & & & & & & & & & & \\
\hline \multirow{2}{*}{6} & BODS & a & 1.61 & -.066 & $.358^{\text {*ink }}$ & $-.213^{* * * * * * * * *}$ & $-.461^{* 2 * * * * *}$ & -.017 & 1 & & & & & & & & & & \\
\hline & & b & 1.66 & -.062 & .060 & $.448^{* * * *}$ & $-.343^{* * * *}$ & $.187^{* * * *}$ & & & & & & & & & & & \\
\hline \multirow{2}{*}{7} & BODM & a & 1.47 & .064 & $.371^{* * * * *}$ & -.091 & -.068 & -.090 & $.298^{* * * *}$ & 1 & & & & & & & & & \\
\hline & BUDM & b & 1.55 & -.057 & $.475^{* * * *}$ & $-.136^{* * * *}$ & .040 & $-.163^{* * * *}$ & -.011 & 1 & & & & & & & & & \\
\hline \multirow{2}{*}{8} & Volatility & a & 1.49 & .090 & -.074 & .063 & $.219^{* * * *}$ & .097 & $-.195^{* * * *}$ & .048 & 1 & & & & & & & & \\
\hline & volatimty & b & 1.46 & $.129^{* * * *}$ & -.065 & .060 & .064 & $.163^{* * * *}$ & $0.088^{*}$ & -.078 & 1 & & & & & & & & \\
\hline \multirow{2}{*}{9} & $\ln \mathrm{Size}$ & a & 1.55 & -.050 & -.005 & -.005 & -.035 & .069 & $-.131^{* * *}$ & .074 & $.453^{* * * *}$ & 1 & & & & & & & \\
\hline & Insize & b & 1.48 & $-.152^{* * * *}$ & $.245^{* * * *}$ & .053 & -.068 & $.165^{* * * *}$ & $.172^{* * * *}$ & $.099^{* * *}$ & $.379^{* * * * *}$ & 1 & & & & & & & \\
\hline \multirow{2}{*}{10} & Tenure & a & 1.24 & .064 & .015 & -.015 & .062 & .023 & .055 & $0.121^{*}$ & -.015 & -.100 & 1 & & & & & & \\
\hline & 1 enure & b & 1.26 & $.363^{* * * *}$ & .033 & $-.173^{* * * *}$ & $.229^{* * * * *}$ & -.070 & -.056 & $.112^{* *}$ & .055 & .074 & 1 & & & & & & \\
\hline \multirow{2}{*}{11} & Profit & a & 1.73 & $.175^{* * * *}$ & .066 & -.035 & $0.122^{*}$ & .048 & .082 & -.040 & $-.188^{* * * *}$ & $-.179^{* * * *}$ & -.087 & 1 & & & & & \\
\hline & Prom & b & 1.74 & -.081 & $-.103^{* *}$ & .025 & -.013 & -.005 & .067 & $-.297^{* * * *}$ & $0.089^{*}$ & $-.127^{* *}$ & $-0.095^{*}$ & 1 & & & & & \\
\hline \multirow{2}{*}{12} & Leverage & a & 1.57 & -.070 & $.302^{* * * *}$ & $-.136^{* * *}$ & $-.177^{* * * *}$ & -.017 & $0.110^{*}$ & $0.106^{*}$ & .100 & $0.120^{*}$ & $.170^{* * * *}$ & $-.434^{* * * *}$ & 1 & & & & \\
\hline & Leverage & b & 2.20 & -.060 & $.183^{* * * *}$ & -.010 & $-.174^{* * * *}$ & -.052 & $.151^{* * * *}$ & .046 & $.107^{* *}$ & $.214^{* * * * *}$ & .064 & $-.293^{* * * *}$ & & & & & \\
\hline \multirow{2}{*}{13} & Firm & a & 1.51 & -.010 & $.276^{* * * *}$ & $-.193^{* * * * * *}$ & $-.292^{* * * *}$ & .021 & $.159^{* *}$ & $0.120^{*}$ & .086 & $.184^{* * * *}$ & $-0.105^{*}$ & $-.137^{* *}$ & .046 & 1 & & & \\
\hline & Value & b & 1.89 & $-.187^{* * * *}$ & $.120^{* * *}$ & $198^{* * * * * *}$ & -.001 & .010 & $.141^{* * * *}$ & -.042 & .029 & $.115^{* * *}$ & .057 & $.470^{* * *}$ & $-.143^{* * * *}$ & & & & \\
\hline \multirow[t]{2}{*}{14} & Firm Size & a & 2.52 & -.005 & $.296^{* * * * * *}$ & $-.224^{* * * * * *}$ & $-.329^{* * * * * *}$ & -.030 & $.375^{* * * * * *}$ & $.280^{* * * * * * *}$ & -.004 & $.202^{* * * * * *}$ & $.245^{* * *}$ & .072 & $0.110^{*}$ & $.323^{* * * *}$ & 1 & & \\
\hline & & b & 4.16 & $-.227^{* * * *}$ & $.493^{* * * *}$ & $.250^{* * * * *}$ & $-.198^{* * * *}$ & .073 & $.432^{* * * *}$ & $.205^{* * * *}$ & .079 & $.380^{* * * *}$ & -.004 & $-.212^{* * * *}$ & $.605^{* * * *}$ & .079 & 1 & & \\
\hline \multirow{2}{*}{15} & Sustain & a & 1.36 & -.051 & .007 & .054 & $-.162^{* * * *}$ & $.174^{* * * *}$ & $.180^{* * * *}$ & $-0.106^{*}$ & -.097 & $-.196^{* * * *}$ & -.039 & $.250^{* * * *}$ & -.041 & $.214^{* * * *}$ & .050 & 1 & \\
\hline & & b & 1.33 & .023 & .025 & $-.112^{* * *}$ & .015 & .024 & -.022 & -.005 & .070 & .032 & $-.221^{* * * *}$ & -.068 & $0.097 *$ & $-.403^{* * * * *}$ & . 021 & & \\
\hline \multirow{2}{*}{16} & $\operatorname{lnGDP}$ & a & 2.64 & -.078 & $.133^{* *}$ & $-.202^{* * * *}$ & $-.473^{* * * *}$ & $-0.106^{*}$ & $.329^{* * * *}$ & -.018 & $-.335^{* * * *}$ & $-0.119^{*}$ & $.185^{* * * *}$ & $.202^{* * * *}$ & -.024 & .043 & $.589^{* * * *}$ & $.162^{* * * *}$ & 1 \\
\hline & IIUDY & $\mathrm{b}$ & 1.45 & $-.341^{* * * *}$ & $.215^{* * * *}$ & $-0.084 *$ & $.102^{* * *}$ & $-.163^{* * * *}$ & -.020 & $0.088^{*}$ & $-.381^{* * * *}$ & $-.107^{* * *}$ & $.197^{* * * *}$ & -.059 & -.010 & $0.096^{*}$ & $.187^{* * * *}$ & $-.127^{* *}$ & 1 \\
\hline
\end{tabular}


The decision to investigate the relationships between dependent and independent variables not only depend on the pairwise correlation results for multicollinearity test. The VIF test is conducted to confirm that no multicollinearity problems exist in the variables. The robustness check for VIF is run for all models either in the pooled OLS (for model 1), fixed-effect model (for model 2) or random-effect model (for model 3 ). The estimators are not seriously affected by the presence of multicollinearity because all values are below than 10 . The highest VIF value is 3.04 , represented by top-six institutional ownerships in panel A, and is 4.16, represented by firm size in panel B. High VIF may reduce the accuracy of the regression estimation, and this is consistent with the advantage of using panel data to minimize collinearity. Without a multicollinearity problem, the accuracy of model estimations for all models is unquestionable. Overall, the analysis indicates that multicollinearity is not detrimental to the results of multiple regression estimation analysis because both pairwise correlation and VIF coefficients do not report multicollinearity in this clustered.

\section{Analysis of Robust Regression Results}

As reported in Table 4, in panel A for LTCBS, pooled OLS, which represents model 1, indicates that the model is significant at $95 \%$ confidence level. This outcome suggests that the relationship exists for the model estimation equation for variables toward yield spreads. This model fit shows higher accuracy in fixed-effect model, which is model 2 , at $99 \%$ confidence level. The results reveal the satisfactory and acceptable result for $\mathrm{R}$-square value within the range of $10 \%$ to $43 \%$ for all models developed. Therefore, the estimation of multivariate robust regression result is valid in explaining the relationship between yield spreads and their determinants for long-term and medium-term issuances used for the study. Model 1 shows that both proxies for institutional ownerships indicate insignificant results on yield spreads. Specifically, with respect to the presence of top-six institutional ownerships in issuer firms, the result is negative. However, the opposite direction is shown by other institutional ownerships, although the performance of yield spreads in this model does not have any relationship with the presence of institutional ownerships in the issuer firms. The findings from this pooled estimation model regression toward model 1 cannot provide empirical evidence of the presence of institutional ownership toward yield spreads. Institutional ownership theory does not apply in long-term issuances. This result is consistent with the study done by Mungniyati (2009) wherein the institutional ownership of Indonesian companies exerts no significant effects on bond yields.

The results revealed by models 2 and 3 indicate that the institutional ownerships have a significant relationship with long-term yield spreads. Top-six institutional ownerships and other institutional ownerships show a positive significant relationship at $99 \%$ and $95 \%$ confidence levels with yield spreads in model 2. Similar results are shown in model 3 with a confidence level of $99 \%$. The positive coefficient of estimations postulates that high other institutional ownership concentration by having large shareholding equity leads to high yield spreads. This result is influenced by volatility and lnGDP as control variables, because both indicate positive significant results on yield spread. This finding justifies that the long-term debt issuances by other institutional ownership lead to high default risk due to volatile YTM and dynamic changes in that current price of GDP at issuance date of these instruments. This outcome is consistent with the research of Fields, Fraser, and Subrahmanyam (2012) who indicated a positive significant relationship between institutional ownership and the cost of bank debt. In panel B, all models show that both proxies for institutional ownerships indicate insignificant results on yield spreads. The presence of institutional ownerships does not have any significant relationship with mediumterm yield spreads. This result is consistent with the study by Pozen (1994) wherein institutional 
investors become reluctant activists when their approaches to have informal discussion with top management, such as the BOD, are a means to fight for control of the firm's decision-making, particularly in investment.

With respect to BOD characteristics, only $\mathrm{CEO}$ duality shows a significant relationship with yield spreads in both panels A and B. Firms need to have a separate position for the CEO and chairman to reduce default risk, because the $\mathrm{CEO}$ and chairman can exert their best effort in fulfilling their duties and responsibilities as recommended in MCCG 2014 code of best practice. Parallel with Islamic principles, top leaders must hold their position as trust (amanah) and responsibility to perform well. High credibility and integrity become important elements to the BOD. Moreover, Nu Htay and Salman (2013) claimed that the main duty of the BOD as an agent to principal (shareholder) is to disclosure all relevant information required and be transparent in performing their tasks. Unfortunately, some directors fail to do so and jeopardize the Islamic values in relation to the principle of transparency (Nu Htay \& Salman, 2013).

Table 4: Robust Regressions Results for LTCBS and MTCBS

\begin{tabular}{|c|c|c|c|c|c|c|}
\hline $\begin{array}{l}\text { Debt Instrument } \\
\text { Category: }\end{array}$ & \multicolumn{3}{|c|}{ Panel A: LTCBS } & \multicolumn{3}{|c|}{ Panel B: MTCBS } \\
\hline \multicolumn{7}{|c|}{ Dependent variable: Yield Spread } \\
\hline \multirow{3}{*}{ Explanatory variables } & Model & & & & & \\
\hline & OLS & FE & $\mathrm{RE}$ & OLS & FE & $\mathrm{RE}$ \\
\hline & (1) & (2) & (3) & (1) & (2) & (3) \\
\hline Intercept & 5.721 & -9.970 & $-9.500 *$ & $24.800 * * *$ & $13.780 *$ & $15.810^{*}$ \\
\hline \multicolumn{7}{|c|}{ Institutional Ownerships: } \\
\hline Top-six IO & -0.013 & $0.051 * * *$ & $0.036 * * *$ & -0.002 & 0.026 & -0.004 \\
\hline Others IO & 0.0003 & $0.036^{* *}$ & $0.025 * * *$ & -0.001 & -0.020 & -0.009 \\
\hline \multicolumn{7}{|c|}{ Board of Directors Characteristics: } \\
\hline BODR2 & 0.135 & $1.524 * *$ & $1.286 * *$ & $-0.465 * * *$ & -0.339 & -0.395 \\
\hline BODC & -0.132 & 0.793 & 0.757 & 0.051 & 0.117 & 0.0004 \\
\hline BODS & -0.024 & 0.066 & 0.072 & -0.005 & $0.176^{* *}$ & $0.101 * *$ \\
\hline BODM & 0.007 & -0.008 & 0.002 & -0.002 & 0.002 & -0.004 \\
\hline \multicolumn{7}{|l|}{ Issue Characteristics: } \\
\hline Volatility & 0.108 & $0.120 * *$ & $0.124 * *$ & 0.073 & 0.119 & 0.097 \\
\hline $\operatorname{lnSize}$ & -0.116 & 0.0001 & -0.042 & $-0.140 * * *$ & -0.056 & $-0.078 * * *$ \\
\hline Tenure & 0.013 & 0.026 & 0.023 & $0.122 * * *$ & $0.097 * * *$ & $0.095 * * *$ \\
\hline \multicolumn{7}{|l|}{ Issuer Characteristics: } \\
\hline Profit & $0.091 * * *$ & -0.085 & -0.039 & $-0.017 *$ & 0.002 & 0.003 \\
\hline Leverage & 0.026 & 0.035 & 0.009 & $-0.026^{*}$ & -0.015 & -0.023 \\
\hline Firm Value & 0.613 & 0.419 & 0.458 & -0.143 & -0.457 & $-0.363 *$ \\
\hline Firm Size & 0.023 & -0.067 & -0.059 & 0.002 & 0.401 & -0.035 \\
\hline Sustain & -0.024 & -0.007 & -0.008 & 0.001 & 0.001 & 0.001 \\
\hline \multicolumn{7}{|l|}{ Systematic Risks: } \\
\hline $\operatorname{lnGDP}$ & -0.329 & 0.631 & $0.707 *$ & $-1.665^{* * *}$ & $-1.203^{*}$ & $-1.010 *$ \\
\hline Firm fixed effects & No & Yes & No & No & Yes & No \\
\hline No of observations & 256 & 256 & 256 & 405 & 405 & 405 \\
\hline R-squared & 0.1025 & 0.2383 & 0.2294 & 0.4255 & 0.4255 & 0.3724 \\
\hline Adj R-squared & 0.0464 & - & - & 0.4033 & - & - \\
\hline Model Fit (F-stat) & $1.83 * *$ & $4.09 * * *$ & - & $19.21 * * *$ & $16.22 * * *$ & - \\
\hline F-test & - & $12.32 * * *$ & - & - & $8.01 * * *$ & - \\
\hline Wald-chi-squared & - & - & $50.29 * * *$ & - & - & $128.76 * * *$ \\
\hline
\end{tabular}

Notes: The t-statistics of OLS, FE, and RE estimators are reported in parentheses. Asterisks indicate significance at $1 \%(* * *), 5 \%(* *)$, and $10 \%(*)$. 


\section{Conclusion}

The presence of top-six and other institutional ownerships shows positive significant relationship with yield spreads in long-term issuances of corporate bonds and sukuk, but it has no relationship with yield spreads in medium-term issuances. With respect to BOD characteristics, such as CEO duality, board size, and directors' religion, appear to be significant determinants in influencing yield spreads except for the composition of independent directors in the firms. Evidence of CEO duality suggests that the separation of the role between the chairman of directors and CEO is an important determinant for long-term issuances. The implications of the study can be seen in five perspectives. For the theoretical aspects, sukuk investment matches with the conventional theory assumptions for YTM on conventional bonds investment despite differences in the financing structures. In addition, the study provides a significant contribution regarding shareholder, managerial, economic, and policy implications. Compliance with the corporate governance code of best practices by the BOD should be morally anchored to the concepts of trust, mutual consultation, justice, and integrity to ensure consistency with Islamic values. The BOD can be seen as experts in investment and working toward getting the blessing from God. These Islamic ethical values that relate to accountability and governance through religion make good agency relationships and strive to avoid default risk. The issue and issuer characteristics as well as current prices of GDP bear positive and negative implications toward issuers who issued long-term and medium-term debt, respectively. This finding shows a good and bad signal of default risk to an issuer. In particular, an issuer benefits from issuing both medium-term financing instruments, either conventional bonds or sukuk, if the current price of the GDP is high because the default risk will be low. Otherwise, the issuer may issue long-term financing instruments (both or either conventional bonds or sukuk) when the current price of the GDP is low. Issuing long-term debt when GDP is high results in high default risks. The issuer must properly analyze the big/ small size of issuance and long/medium term of issuances to alleviate default risk.

\section{Acknowledgement}

The authors would like to express their gratitude to the Ministry of Education, Malaysia and Universiti Teknologi MARA for funding and facilitating this research project.

\section{References}

Afshar, T.A. (2013). Compare and Contrast Sukuk (Islamic Bonds) with Conventional Bonds, Are they Compatible?. The Journal of Global Business Management, 9(1), 44-52.

Anderson, R.C., Mansi, S.A, \& Reeb, D.M. (2004). Board characteristics, Accounting Report Integrity, and the Cost of Debt. Journal of Accounting and Economics, 37, 315-342.

Andres, P.D. \& Vallelado, E. (2008). Corporate Governance in Banking: The Role of the Board of Directors. Journal of Banking \& Finance, $32,2570-2580$.

Barry, T.A., Lepetit, L. \& Tarazi, A. (2011). Ownership Structure and Risk in Publicly Held and Privately Owned Banks. Journal of Banking \& Finance, 35, 1327-1340.

Benzie, R. (1992). The Development of the International Bond Market. BIS Economic Papers, 32, 1-96. Available at http://bis. hasbeenforeclosed.com/pub1/econ32.pdf

Berle, A. \& Means, G. (1932). The Modern Corporation and Private Property. California Law Review, 21(1), 78-79.

Boubakri, N. \& Ghouma, H. (2010). Control/ Ownership Structure, Creditor Rights Protection, and the Cost of Debt Financing: International Evidence. Journal of Banking \& Finance, $34(10), 2481-2499$. 
Bhojraj, S. \& Sengupta, P. (2003). Effects of Corporate Governance on Bond Ratings and Yields: The Role of Institutional Investors and Outside Directors. Journal of Business, 76, 455-476.

De Vaus, D. (2002). Analyzing Social Science Data - 50 Key Problems in Data Analysis. Landon: SAGE Publications Limited.

Elyasiani, E. \& Jia, J. (2010). Distribution of Institutional Ownership and Corporate Firm Performance. Journal of Banking \& Finance, 34(3), 606-620.

Ertugrul, M. and Hegde, S. (2008). Board Compensation Practices and Agency Costs of Debt. Journal of Corporate Finance, 14, 512531.

Fama, E.F. \& Jensen, M.C. (1983). Separation of Ownership and Control. Journal of Law and Economics, 26, 301-325.

Fields, L.P., Fraser, D.R. \& Subrahmanyam, A. (2012). Board Quality and the Cost of Debt Capital: The Case of Bank Loans. Journal of Banking \& Finance, 36, 1536-1547.

Hawkins, J. (2002). Bond Markets and Banks in Emerging Economies. BIS Papers no. 11 (June-July).

Hesse, H., Jobst, A.A. \& Sole, J. (2008). Trends and challenges in Islamic finance. World Economy, 9, 175-193.

Homer, S. (1975). The Historical Evolution of Today's Bond Market. National Bureau of Economic Research, Explorations in Economic Research, 2(3), (Regional Stock Exchanges in a Central Market System), Available at: http:// www.nber.org/books/conf75-1.

Howell, D.C. (2007). Statistical Methods for Psychology. 6th Edition. Belmont, CA: Thompson.
Huang, Y.S. \& Wang, C-J. (2015). Corporate governance and risk-taking of Chinese firms: The role of board size. International Review of Economics and Finance, 37, 96-113.

Jensen, M.C. \& Meckling, W.H. (1976). Theory of the Firm: Managerial Behavior, Agency Costs and Ownership Structure. Journal of Financial Economics, 3(4), 305-360.

Jiambalvo, J., Rajgopal, S., \& Venkatachalam, M. (2002). Institutional ownership and the extent to which stock prices reflect future earnings. Contemporary accounting research, 19(1), 117-145.

Jobst, A. A. (2006). Asset securitisation as a risk management and funding tool: What small firms need to know. Managerial Finance, 32(9), 731-760.

John, K. \& Senbet, L.W. (1998). Corporate governance and board effectiveness. Journal of Banking \& Finance, 22, 371-403.

Khalid, A. M. (2007). Bond Market Developments in Emerging Markets: Prospects and Challenges for Pakistan. SBP Research Bulletin, 3(1), 43-62.

Liu, Y., \& Jiraporn, P. (2010). The Effect of CEO Power on Bond Ratings and Yields. Journal of Empirical Finance, 17(4), 744-762.

López-Iturriagaa, F., García-Meca, E \& TejerinaGaite, F. (2015). Institutional directors and board compensation: Spanish evidence. BRQ Business Research Quarterly, 18, 161-173.

Mungniyati. (2009). The Effect of Corporate Governance and Earnings Information on Bond Ratings and Yields. Jurnal Bisnis Dan Akuntansi, 11(2), 129-141.

Nguyen, T., Locke, S., \& Reddy, K. (2015). Ownership concentration and corporate performance from a dynamic perspective: Does national governance quality matter? 
International Review of Financial Analysis, 41, 148-161.

Nu Htay, S. N. \& Salman, S. A. (2013). Balanced Score Card Approach for Better Shariah Corporate Governance. American Journal of Applied Sciences, 10(12), 1553-1557.

Pozen, R. C. (1994). Institutional Investors: The Reluctant Activists. Harvard Business Review (January-February), 140-49.

Qiu, L. X. (2006). Which Institutional Investors Monitor? Evidence from Acquisition Activity. Brown Economics Working Paper Series No. 2004-21 (June 2006) and Yale ICF Working Paper No. 04-15. Available at: http://ssrn.com/ abstract $=521803$.

Reilly, F. K. , Wright, D. J. \& Gentry, J.A. (2009). Historic Changes in the High Yield Bond Market. Journal of Applied Corporate Finance, 21(3), 65-79.

Shailer, G. \& Wang, K. (2015). Government ownership and the cost of debt for Chinese listed corporations. Emerging Markets Review, $22,1-17$.
Sharma, K. (2001). The underlying constraints on corporate bond market development in southeast Asia. World Development, 29(8). 1405-1419.

Tabachnick, B.G. \& Fidell, L.S. (2007). Using Multivariate Statistics (5th Edition). Needham Heights, MA: Allyn \& Bacon.

Tanaka (2014). Corporate governance and the cost of public debt financing: Evidence from Japan. Journal of the Japanese and International Economies, 34, 315-335.

Zakaria, Z., Hussin, Z., Noordin, N. \& Mohamed Sawal, M.Z. (2010). Financial crisis of 1997/1998 in Malaysia: causes, impacts and recovery plans. Voice of Academia, 5(1). 79-96. 